\title{
Factors Associated with Risk of Infection in Hospitalized Patients with Cancer: an Integrative Review

\begin{abstract}
Aryele Rayana Antunes de Araújo', Alexsandra Rodrigues Feijão ${ }^{1}$, Cristiane da Câmara Marques ${ }^{1}$, Annanda Luyza Carias Maia1, Isabela Pereira de Medeiros1, Emily Kathiene Silva Mesquita', Anne Karine Freire Caldas ${ }^{1}$
\end{abstract}

\section{Abstract}

Background: To identify through the scientific literature, the risk factors of the nursing diagnosis "risk of infection" in studies conducted in hospitalized cancer patients.

Method: This is an integrative literature review performed in databases Latin American Literature in Health Sciences; PubMedCentral, Cumulative Index toNursingandAllied Health Literature; Medical LiteratureAnalysis and Retrieval System Online; Scopus Info Site; Web of Science; Nursing Databases; and Bibliographical Index Español de Ciencias de la Salud in January 2016, using the keywords of Health Sciences and Medical Subject Headings: (Neoplasms OR Cancer), "Cross Infection", "Risk Factors". Inclusion criteria were scientific articles available in full, with results of at least one risk factor for the nursing diagnosis studied in patients aged 18 years of age or older. After the analysis, the final sample consisted of 59 articles.

Results: Predominated studies outside Brazil with the level of evidence III.2. Out of 19 risk factors for diagnosis, 11 were identified in the literature for this population.

Conclusion: In studies of hospitalized cancer population, risk factors of nursing diagnosis "risk of infection" were found.

\section{Introduction}

Cancer is a major cause of mortality worldwide with approximately 14 million new cases and 8.2 million related deaths in 2012. The prospect
1 Universidade Federal do Rio Grande do Norte, Natal/RN, Brasil.

Contact information:

Aryele Rayana Antunes de Araújo.

Address: Universidade Federal do Rio Grande do Norte, Centro de Ciências da Saúde, Departamento de Enfermagem. Avenida Salgado Filho, S/N, Lagoa Nova, Natal, RN, Brasil. CEP: 59078970.

झ" aryelearaujo_ufrn@yahoo.com.br

Keywords

Nursing Diagnosis; Cross

Infection; Risk Factors;

Neoplasms 
is that in two decades, the number of new cases disease reaches 22 million. [1]

Infections related to health care are the most common adverse events in the provision of health care around the world and represent a significant cause of morbidity and mortality. The high frequency of this event is directly associated with the use of invasive devices and procedures, and inversely to the income of countries and conditions of health infrastructure. [2]

Oncologic patients are especially susceptible to infections related to healthcare for two main reasons: the first one, by the physiological manifestations of the disease culminating in depletion of cell and humoral function of the immune system, and immunosuppression caused by cytotoxic chemotherapy treatment. The second one, because patients are exposed to potentially pathogenic microorganisms in treatment. As a result of the environment, there is an increased length of hospital stay, complications, and deaths among those who developed infections compared to those who did not develop infections. [3]

Among the risk factors related to the development of hospital infections in oncology patients, there is age, presence of comorbidities, especially hypertension, diabetes mellitus and smoking; the hospitalization; and invasive procedures. Hospital infection is associated with higher rates of mortality in patients undergoing cancer therapies. [4]

The nursing staff conceives a body of professionals who perform therapeutic actions and comfort to these patients and the proper attribution is closer, being directly responsible for the care. Such care is a set of efforts aimed at human beings, in which it is up to the nursing staff to cope with the disease in which there is a demand for prolonged treatment and management of expected adverse effects. [5]

The systematization of Nursing care organizes professional work on the method, personnel, and instruments, enabling the implementation of the nursing process (NP). This NP allows nurses to iden- tify, understand, describe, intervene, resolve and achieve results before the health problems. Given this, the Nursing Diagnosis (ND) becomes inserted into this NP. [6]

The use of nursing diagnosis risk of infection as the first stage of the nursing process is justified by the need to identify risk factors, which the patients are submitted and then a directed care plan elaborated to reduce the development of this adverse event.

Given the above, the aim of this study is to identify the literature of the risk factors nursing diagnosis "risk of infection" in studies conducted with hospitalized oncologic patients.

\section{Methodology}

This is an integrative literature review method that has the purpose of analysis and synthesis of various independent studies addressing the same subject, in an organized and orderly manner, to support critical thinking and improvements in clinical practice. [7]

Therefore, six stages were used consisting of elaboration of the guiding question; search or sampling in the literature; data collection; critical analysis of the included studies; discussion of the results; and presentation of the integrative review. In this study, the guiding question was: what are the risk factors related to the nursing diagnosis "risk of infection" in hospitalized people with cancer found in the literature? [7]

The following inclusion criteria were adopted: 1. scientific articles available in full; 2 . Studies with patients aged 18 years of age or older; 3. Studies presenting at least one defining characteristic of nursing diagnosis studied in the results. The studies in editorial format, letter to the editor and literature review were excluded.

The searches were conducted from January 19 to 30, 2016 in the databases and virtual libraries: Latin American Literature in Health Sciences; PubMed Central, Cumulative Index to Nursing and 
Allied Health Literature; Medical Literature Analysis and Retrieval System Online; Scopus Info Site; Web of Science; Nursing Databases; and Bibliographical Index Español de Ciencias la Salud.

Using keywords in Health Sciences (DeCS) and Medical Subject Headings (MeSH): (Neoplasms OR Cancer)/(Neoplasms OR Cancer), "Infection"/"Cross Infection", Risk Factors/"Risk Factors" by the operator Boolean AND. In SCOPUS, the search was conducted in a controlled manner by the excessive number of articles found while in the other the search was not controlled.

The choice of the keywords was due to the absence of the descriptor "risk of infection" in the nomenclature DeCS/MeSH and the lack of studies that addressed risk factors for nosocomial infection development when using the descriptor "nursing diagnosis" at intersections.

The study selection procedure was performed by peers, independently from a data collection instrument created by the authors, containing the following information: author/year basis, title, journal, the reference level of evidence and risk factor. Later, there was a meeting to define the articles that would be selected to compose the study, based on the consensus between the pair.

For the selection of studies, the PRISMA recommendations were used [8], as shown in Figure 1. With the application of the study descriptors, there were 640 articles found in the eight surveyed databases. After analyzing all the bases and their respective intersections, 22 articles were counted only once for being duplicated. Then, there was the reading of titles and abstracts, selecting 155 studies considered potentially relevant. After the review, 95 studies were selected for reading in full. After the full-text reading of the articles, it was found that 59 articles responded to the objective of this study and were included in the final sample of the review, two of LILACS, three of CINAHL, seven of MEDLINE, thirty-nine of SCOPUS and eight of PUBMED (Figure 1) (Table 1).

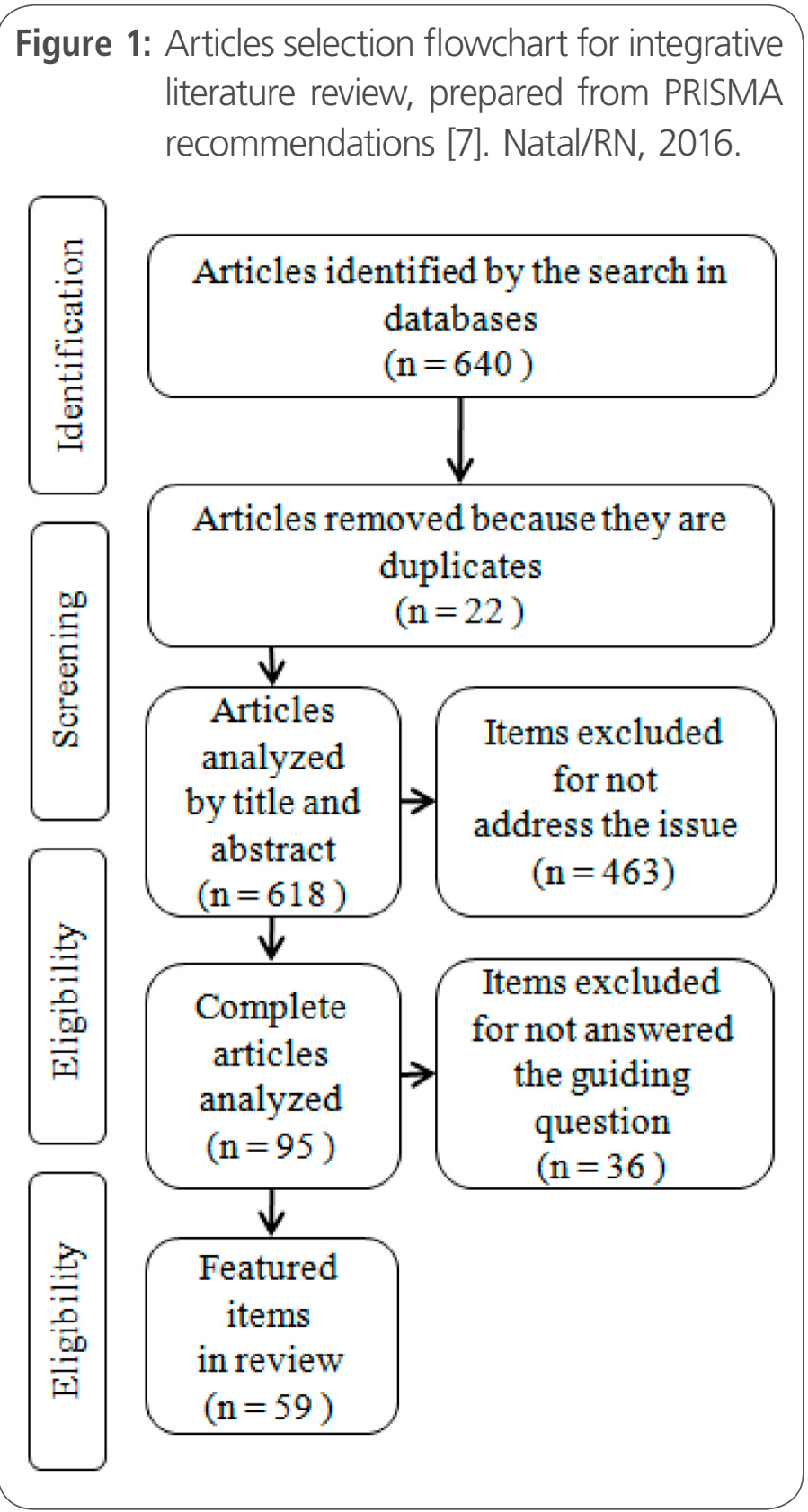

The selected articles were classified according to level of evidence adopting as a parameter of the Institute Joanna Briggs, which employs a compound classification system of four levels, "Level I: Evidence obtained from a systematic review containing only randomized controlled trials; Level II: Evidence obtained from at least one randomized controlled trial; Level III.1: Evidence obtained from well-designed controlled trials without randomization; Level III.2: Evidence obtained from well-designed cohort studies or case-control analytic studies, preferably 
Table 1. Distribution of the domains and facets of QoL. João Pessoa, PB, 2015.

\begin{tabular}{|l|l|c|c|c|c|c|c|c|}
\hline \multicolumn{1}{|c|}{ Databases } & Search strategy & F & D & AT & AF \\
\hline Lilacs & (Neoplasias OR Câncer) AND "Infecção Hospitalar" AND "Fatores de Risco." & 14 & 2 & 5 & 4 & 2 \\
\hline Cinahl & (Neoplasms OR Cancer) AND "Cross Infection" AND "Risk Factors" & 54 & 0 & 8 & 4 & 3 \\
\hline Medline & (Neoplasias OR Câncer) AND "Infecção Hospitalar" AND "Fatores de Risco." & 207 & 3 & 47 & 17 & 7 \\
\hline Scopus & KEY (Neoplasms OR Cancer) AND "Cross Infection" AND "Risk Factors" & 282 & 5 & 58 & 53 & 39 \\
\hline Pubmed & (Neoplasms OR Cancer) AND "Cross Infection" AND "Risk Factors" & 69 & 12 & 31 & 12 & 8 \\
\hline Web ofscience & (Neoplasms OR Cancer) AND "Cross Infection" AND "Risk Factors" & 9 & 0 & 5 & 5 & 0 \\
\hline Bdenf & (Neoplasias OR Câncer) AND "Infecção Hospitalar" AND "Fatores de Risco." & 3 & 0 & 1 & 0 & 0 \\
\hline Ibecs & (Neoplasias OR Câncer) AND "Infecção Hospitalar" AND "Fatores de risco" & 2 & 0 & 0 & 0 & 0 \\
\hline Total & & 640 & 22 & 155 & 95 & 59 \\
\hline
\end{tabular}

${ }^{\star}$ F: Found. ${ }^{* *}$ D: Duplicated. ${ }^{* * *}$ AT: Abstract title. ${ }^{* * *}$ AF: Analysis in full. ${ }^{* * * * * S}$ : Selected

Table 2. Risk factors for the development of nosocomial infection identified in patients hospitalized with cancer. Natal/RN, 2016.

\begin{tabular}{|c|c|}
\hline & N (\%) \\
\hline \multicolumn{2}{|l|}{ Inadequate primary defenses } \\
\hline $\begin{array}{l}\text { Change in skin integrity (invasive } \\
\text { procedures) }[10,11,12,13,14,15,16,17 \text {, } \\
18,19,20,21,22]\end{array}$ & $35(59.3 \%)$ \\
\hline $\begin{array}{l}\text { Changing the peristalsis }[23,24,25,26,27 \text {, } \\
\text { 28] }\end{array}$ & $4(6.8 \%)$ \\
\hline Smoking $[23,29,30,31]$ & $4(6.8 \%)$ \\
\hline \multicolumn{2}{|l|}{ Inadequate secondary defenses } \\
\hline $\begin{array}{l}\text { Leukopenia }[19,24,25,26,29,32,33,34, \\
\begin{array}{l}35,36,37,38,39,40,41,42,43,44,45 \\
46,47,48,49,50,51,52,53,54,55,56\end{array} \\
57,58]\end{array}$ & $25(4.2 \%)$ \\
\hline $\begin{array}{l}\text { Immunosuppression }[23,25,29,40,43,53 \text {, } \\
54,59]\end{array}$ & $11(18.6 \%)$ \\
\hline Haemoglobin decrease $[10,21,23,39]$ & $2(3.4 \%)$ \\
\hline \multicolumn{2}{|l|}{ Malnutrition } \\
\hline Severe malnutrition $[31,60]$ & $2(3.4 \%)$ \\
\hline \multicolumn{2}{|l|}{ Chronic disease } \\
\hline $\begin{array}{l}\text { Diabetes }[10,12,16,17,23,26,31,32,37 \text {, } \\
43,45,59,61,60,62]\end{array}$ & $16(27.1 \%)$ \\
\hline $\begin{array}{l}\text { Chronic Kidney feilure }[12,16,25,26,32, \\
37,43,59,63,62]\end{array}$ & $10(16.9 \%)$ \\
\hline Hypertension $[23,31,32,37,43,59,61]$ & $3(5 \%)$ \\
\hline Obesity $[10,23,62]$ & $3(5 \%)$ \\
\hline
\end{tabular}

from more than one center or research group; III. 3 Level: Evidence obtained from multiple time series with or without intervention and dramatic results in uncontrolled experiments; Level IV Opinion of respected authorities based on clinical criteria and experience, descriptive studies or expert committee reports. As for the ethical aspects of the studies, of all articles studied respected the authorship. [9]

The presentation of results and discussion of the data occurred in a descriptive way, by providing the applicability of the review elaborated and provide grants to nurses on the use of nursing diagnosis in this population.

\section{Results}

This study analyzed 59 articles that met the proposed theme. Studies with evidence level III. 2 predominated, which corresponds to the Evidence obtained from well-designed cohort studies or casecontrol analytic studies. As the year of publication, studies have ranged between 1988 and 2015, with 27 articles (45.8\%) in the last five years.

Out of the articles analyzed, it was observed that most articles come from outside Brazil, with good indexing and evaluation of high quality for nursing. Five articles were published in Brazilian journals, 
three of them in The Brazilian Journal of Infectious Diseases. As to the place of study and language, three studies were conducted in Brazil, one in the state of Rio de Janeiro [10] and two in São Paulo. $[11,12]$ Only one of them was presented in Portuguese.

Risk factors for infection risk nursing diagnosis to cancer patients at risk of hospital infections addressed in articles were grouped in defense inadequate primary categories, inadequate secondary defenses, malnutrition and chronic disease, and are listed in Table 2, respectively, according to the frequency with which they were found in studies.

\section{Discussion}

From the selected studies, there was a predominance of evidence presented in III. 2 level obtained from well-designed cohort studies or case-control analytic studies, implying the recommendations of the best results for application in professional practice mainly in the choice of assessment instruments and intervention proposals for the control of risk factors for infection. However, it is noteworthy the lack of randomized clinical trial having as focus the nursing care and the risk of infection in this population.

As for risk factors defenses, inadequate primary for cancer patients at risk of nosocomial infection stands out the invasive procedure which was present in 35 articles. Of them, 19 articles addressed the central venous catheter (CVC) as a risk factor, while the surgical procedure was listed in eighteen studies.

Intravenous catheters have brought great benefits to the treatment and control of disease symptoms, besides being used as parenteral feeding route in case of impossibility of enteral nutrition. However, studies point out that these pathways ultimately establish direct contact between the external environment and the bloodstream and thus increasing the likelihood of bloodstream infection development that can progress to sepsis with severe consequences. $[65,66]$

Moreover, these accesses act as a foreign body, causing inflammation at the insertion site, resulting in decreasing of local anti-infection defense, allowing infections are established from small inoculants. Thus, every effort should be effect to prevent the development of this event which is a predictor of increased morbidity and mortality in this patients. [67]

During the hospitalization in oncology units, intravenous therapy is necessary at all stages of treatment, requiring venous access with good conditions of infusion medications, hydration, exams collection, and nutrition. These needs are met with the viability of central venous catheters, particularly of long-term, mainly used in antineoplastic chemotherapy administration. The increased exposure of this population to this type of catheterization makes them more vuleráveis the development of bloodstream infections related to these devices. [68]

A study in Japan studied the economic effect of infections related to central venous catheters and identified a substantial additional cost for the treatment of these infections, which include medications and medical supplies, and fees techniques. [69]

American study evaluated complications and postoperative mortality in a population with cancer, and the local surgical infection was the second more frequent complication. [70] This is a serious problem of hospital infections, for its incidence, morbidity, mortality, and financial costs. According to the Center for Disease Control (CDC), the factors supporting the occurrence of ISC are related to the patient, the surgical procedure, and the microorganism. [71]

Other factors favor and increase the risk infection related to the surgical place to undergo chemotherapy or radiotherapy before surgery. The radiotherapy causes a variety of tissue damage and vascular lesions leading to ischemia and compromises 
the venous return and lymphatic drainage reducing the oxygen supply to tissue irradiated and therefore local defenses [72].Chemotherapy decreases the proliferation of rapidly growing cells such as blood responsible for immunity, and the cells of body tissues, including their skin, complicating the healing process. [73]

Also regarding to inadequate primary defenses, inadequate peristalsis was found in our study in the occurrence of diarrhea among patients in the sample and stands out as a facilitator of infections development during its occurrence, the pathogens promote the synthesis and cytokine liberation which increases the inflammatory cascade, and aggravate epithelial injury through the release of reactive oxygen species, leading to inflammatory segregation. [74]

As for the inappropriate peristalsis listed as a risk factor by NANDA, it is known that the intestine actively participates in protecting the body against infection, since it is responsible for the synthesis of substrates used as harmful microorganisms barrier. Instability caused by episodes of diarrhea is responsible for the death of enterocytes, damaging the digestive, absorptive and protective capabilities allowing the flow of toxins through the intestine, which may relate to including a larger load infection and further damage to the ileum. [75]

As for smoking, this generates systemic and local changes, which strongly affect the respiratory tract, affecting the immune response, mechanical barrier of the respiratory system and mucociliary transport which is considered an important defense mechanism of the respiratory tract because it imprisons and expels the aggressors' agents. The nicotine and other compounds present in the smoke have a suppressive effect on the immune system, which explains the increase in respiratory tract infection. [76]

Regarding leukopenia, medicines used to combat the sick cells and also destroy some of the healthy cells of the body. Bone marrow cells are quite susceptible to aggression caused by chemotherapeutic agents. As a result, leukocytes can be interfered with their production, in their fall determining blood counts. Among leukocytes, neutrophils are, in most cases, the front line of defense of the body. For this reason, when they are too low, the risk of infection is higher. [77]

Concerning risk factors inadequate defenses secondary, immune-suppression was found in a significant portion of the study. This can be caused by extensive use of immune-suppressive agents and glucocorticoids used in treatment antineoplastic and the use of antibiotics as influencers of immunesuppression. Glucocorticoids induce an increase in white blood cells and lymphopenia to compromise the growth, differentiation and lymphocyte proliferation by a decrease in Interleukin [2], affecting T-lymphocytes predominantly. Thus, the prolonged use of glucocorticoids enables the appearance of fungus infections, bacteria, and viruses that may generate severe disseminated infections. [78]

Indiscriminate use of antibiotics triggers and accelerates the defense mechanisms of bacteria, which by genetic mutations, they develop a resistance to these drugs, reducing their efficiency. This problem becomes relevant to public health since these drugs resistance happens at higher speeds than the development of new drugs. [79]

As regards the risk factor reduction in hemoglobin concentration, this is considered to be one factor that impairs the transport of oxygen to the tissues, chronic blood causing chronic blood loss, skin, and mucosal changes, gastrointestinal disturbances, weakness, palpitation, followed by infectious processes or prolonged inflammatory. [80]

As to malnutrition risk factor, this enables a wide variety of infectious diseases. The response of the immune system depends on cell replication and synthesis of protein active compounds, and this process dependent on nutritional status. Calories, amino acids, and fat-soluble vitamins are nutrients for which reduced availability causes a deficit in the immune system, such as decreased of humoral an- 
tibodies and the surface of mucosal cell-mediated immunity, the bactericidal activity of phagocytes, among others. [81]

Concerning the chronic disease risk factor, studies highlight the bloodstream infection may also be due to the immune suppression associated with hyperglycemia direct consequence of diabetes. For this significantly decreases the function of neutrophils and monocytes through chemotaxis, and interfere with the phagocytic, and bactericidal function. [82, 83]

In chronic kidney disease and hypertension leads to tissue injury that carries on an ongoing immune stimulation. This favors the complete tissue destruction, installation, and disease progression. The persistent glomerular injury produces capillary pressure, increased glomerular filtration, and passage of proteins into the tubular fluid; glomerular origin of proteinuria increases the production of angiotensin II and promotes the release of inflammatory mediators, the cytokines. [84]

About obesity risk factor, excess adipose tissue enhances the formation of adipokines promoting negative impact on certain bodily functions, including the response of the immune system. The adipocytes secrete cytokines that allow the release of factors related to inflammation. [85]

\section{Conclusion}

After analysis of the studies, it was found that the nursing diagnosis "risk of infection" can be identified in cancer patients because of the risk factors listed 19 by NANDA, 11 have been identified in the literature for this population. The most common risk factors found in the results were "change in skin integrity" and "chronic disease," respectively.

The identification of risk factors for the development of infection in hospitalized patients with cancer is an essential activity for the monitoring of a committed nursing to quality of care and the possibility of minimizing adverse events related to health assistance. Thus, developed nursing care enables accurate monitoring of risk factors and early intervention for those controllable factors to minimize infections and reduce morbidity and mortality associated with them.

\section{References}

1. World Health Organization. World Cancer Report, Lyon: International Agency for Researchon Câncer; 2014

2. Oliveira AC, Paula AO. Healthcare-associated infections in thecontextofpatientsafety: past, present and future. Rev Min Enferm. 2013 Jan/Mar; 17(1): 221-224

3. Apostolopolou E, Raftopoulos V, Terzis K, Pissaki K, Pagoni M, Delibasi S. Infection probability score, APACHE ॥ and KARNOFSKY scoring systems as predictors of infection onset in haematology-oncology patients. Blackwell Publishing Ltd, Journal of Clinical Nursing, 19: 1560-68

4. Feitosa RGF, Fernandes AM, Narciso Jr J, Araújo Jr ON, Costa FA, Cavalcante LDW. Analysis of the incidence of surgical site infection in oncologic surgery of the digestive tract in Hospital Geral de Fortaleza. Medicina (Ribeirão Preto) 2014; 47(2):157-64

5. Silva RCV, Cruz EA. Planejamento da assistência de enfermagem ao paciente com câncer: reflexão teórica sobre as dimensões sociais. Esc. Anna Nery Rev. Enferm. 2011 Jan/Mar; 15(1): 180-5.

6. Barros ALL. Anamnese e exame físico: avaliação diagnostica de enfermagem no adulto. Artmed; 2016

7. Souza MT, Silva MD, Carvalho R. Revisão integrativa: o que é e como fazer. Einstein,2010 jan./mar; 8(1):102-6

8. Lillemoen L, Pedersen R. Ethical challenges and how to develop ethics support in primary healthcare. NursEthics. 2012; 20(1):96108.

9. Karino ME, Felli VEA. Enfermagem baseada em evidências: avanços e inovações em revisões sistemáticas. CiencCuidSaude. 2012; 11: 11-5.

10. Martins C, Faria L, Souza M, Camello T, Velasco E, Hirata $\mathrm{R} J \mathrm{~J}$, et al. Microbiological and host features associated with corynebacteriosis in cancer patients: a five-year study. Mem Inst Oswaldo Cruz. 2009; 104(6):905-13.

11. Barbosa HF, Reis FJC, Carrara HHA, Andrade JM. Fatores de risco para infecções de sítio cirúrgico em pacientes operadas por câncer de mama. Rev. Bras. Ginecol. Obstet. 2004; 26(3): 227-32.

12. Silva CPR, Amarante JMB, Lacerda RA, Biancalana MLN. Klebsiella pneumoniae outbreak in a cancer unit of a general hospital - predisposing factors and evaluation of the impact of intervention measures. Braz J Infect Dis. 2005; 9(3): 226-30.

13. Crosby-Nwaobi R, Faithfull S. High risk of urinary tract infections in post-operative gynecology patients: a retrospective case analysis. Eur J Cancer Care. 2011; 20(6):825-31. 
14. Horasan ES, Ersoz G, Horoz M, Göksu M, Karacorlu S, Kaya A. Risk factors for infections caused by multidrug-resistant bacteria in patients with solid tumours. Scand J Infect Dis. 2011; 43(2):107-11

15. Vayisoğlu Y, Özcan C, Horasan ES, Öztürk C, Ismi O, Görür K. The influence of direct rigid laryngoscopy on the nosocomial colonization and bacteremia. J Craniofac Surg. 2014; 25(1):8992.

16. Henao-Martínez AF, González-Fontal GR, Castillo-Mancilla JR, Yang IV. Enterobacteriaceae bacteremias among cancer patients: an observational cohort study. Int J Infect Dis. 2013; 17(6):374-8.

17. Kang $\mathrm{Cl}$, Chung DR, Ko KS, Peck KR, Song JH. Risk factors for infection and treatment outcome of extended-spectrum $\beta$-lactamase-producing Escherichia coli and Klebsiella pneumoniae bacteremia in patients with hematologic malignancy. Ann Hematol. 2012; 91(1):115-21.

18. Chemaly RF, Hachem RY, Husni RN, Bahna B, Abou Rjaili G, Waked $A$, et al. Characteristics and outcomes of methicillinresistant Staphylococcus aureus surgical-site infections in patients with cancer: a case-control study. Ann Surg Oncol. 2010; 17(6):1499-506.

19. Chaberny IF, Ruseva E, Sohr D, Buchholz S, Ganser A, Mattner $F$, et al. Surveillance with successful reduction of central lineassociated bloodstream infections among neutropenic patients with hematologic or oncologic malignancies. Ann Hematol. 2009; 88(9):907-12.

20. Fukuta $Y$, Muder RR, Agha ME, Clarke LG, Wagener MM, Hensler AM, et al. Risk factors for acquisition of multidrugresistant Acinetobacter baumannii among cancer patients. Am J Infect Control. 2013; 41(12):1249-52.

21. Chen J, Pan QS, Hong WD, Pan J, Zhang WH, Xu G, et al. Use of an artificial neural network to predict risk factors of nosocomial infection in lung cancer patients. Asian Pac J Cancer Prev. 2014; 15(13):5349-53

22. Fukuta $Y$, Muder RR, Agha ME, Clarke LG, Wagener MM, Hensler AM, et al. Risk factors for acquisition of multidrugresistant Acinetobacter baumannii among cancer patients. Am J Infect Control. 2013; 41(12):1249-52

23. Liss BJ, Vehreschild JJ, Cornely OA, Hallek M, Fätkenheuer $\mathrm{G}$, Wisplinghoff $\mathrm{H}$, et al. Intestinal colonisation and blood stream infections due to vancomycin-resistant enterococci (VRE) and extended-spectrum beta-lactamase-producing Enterobacteriaceae (ESBLE) in patients with haematological and oncological malignancies. Infection. 2012; 40(6):613-9.

24. Omeis IA, Dhir M, Sciubba DM, Gottfried ON, McGirt MJ, Attenello FJ, et al. Postoperative surgical site infections in patients undergoing spinal tumor surgery: incidence and risk factors. Spine.2011; 36(17):1410-9.
25. Rauenzahn S, Truong Q, Cumpston A, Goff L, Leadmon S, Evans $K$, et al. Predictors and impact of thirty-day readmission on patient outcomes and health care costs after reduced-toxicity conditioning allogeneic hematopoietic cell transplantation. Biol Blood Marrow Transplant. 2014; 20(3):415-20.

26. Gweon TG, Choi MG, Baeg MK, Lim CH, Park JM, Lee IS, et al. Hematologic diseases: High risk of Clostridium difficile associated diarrhea. World J Gastroenterol. 2014; 20(21): 66026607.

27. Chen J, Pan QS, Hong WD, Pan J, Zhang WH, Xu G, et al. Use of an artificial neural network to predict risk factors of nosocomial infection in lung cancer patients. Asian Pac J Cancer Prev. 2014; 15(13):5349-53.

28. Gifford AH, Kirkland KB. Risk factors for Clostridium difficileassociated diarrhea on an adult hematology-oncology ward. Eur J Clin Microbiol Infect Dis. 2006; 25(12):751-5.

29. Apisarnthanarak A, Fraser VJ, Dunne WM, Little JR, HoppeBauer J, Jennie L, et al. Stenotrophomonas maltophilia Intestinal Colonization in Hospitalized Oncology Patients with Diarrhea. Clin Infect Dis. 2003; 37(8):1131-35.

30. Kang Cl, Chung DR, Ko KS, Peck KR, Song JH. Risk factors for infection and treatment outcome of extended-spectrum $\beta$-lactamase-producing Escherichia coli and Klebsiella pneumoniae bacteremia in patients with hematologic malignancy. Ann Hematol. 2012; 91(1):115-21.

31. Park CH, Kim H, Kang YA, Cho IR, Kim B, Heo SJ, et al. Risk factors and prognosis of pulmonary complications after endoscopic submucosal dissection for gastric neoplasia. Dig Dis Sci. 2013; 58(2):540-6.

32. Penel N, Fournier C, Roussel-Delvallez M, Lefebvre D, Kara A, Mallet $Y$, et al. Prognostic significance of wound infections following major head and neck cancer surgery: an open noncomparative prospective study. Support Care Cancer. 2004; 12(9):634-9.

33. Lin YT, Liu CJ, Fung CP, Tzeng CH. Nosocomial Klebsiella pneumoniae bacteraemia in adult cancer patients-characteristics of neutropenic and non-neutropenic patients. Scand J Infect Dis. 2011; 43(8):603-8.

34. Henao-Martínez AF, González-Fontal GR, Castillo-Mancilla JR, Yang IV. Enterobacteriaceae bacteremias among cancer patients: an observational cohort study. Int J Infect Dis. 2013; 17(6):374-8.

35. Gayet-Ageron A, Iten A, Delden VC, Farquet N, Masouridi-Levrat $S$, Von Dach $E$, et al. In-hospital transfer is a risk factor for invasive filamentous fungal infection among hospitalized patients with hematological malignancies: a matched case-control study. Infect Control Hosp Epidemiol. 2015; 36(3):320-8.

36. Li D, Chen Y, Zhang W, Zheng S, Zhang Q, Bai C,et al. Risk factors for hospital-acquired bloodstream infections caused by extended-spectrum $\beta$-lactamase Klebsiella pneumoniae among cancer patients. Ir J Med Sci. 2014; 183(3):463-9. 
37. Ibrahim KY, Pierrotti LC, Freire MP, Gutierrez PP, Duarte Ldo $P$, Bellesso $M$, et al. Health care-associated infections in hematology-oncology patients with neutropenia: a method of surveillance. Am J Infect Control. 2013; 41(11):1131-3.

38. Aydemir H, Piskin N, Kokturk F, Gökmen A, Akduman D. Healthcare associated bacteremia in geriatric cancer patients with febrile neutropenia.J Geriatr Oncol. 2013; 4(2):190-5.

39. Vardi A, Sirigou A, Lalayanni C, Kachrimanidou M, Kaloyannidis P, Saloum R, et al. An outbreak of Burkholderia cepacia bacteremia in hospitalized hematology patients selectively affecting those with acute myeloid leukemia. Am J Infect Control. 2013; 41(4):312-6.

40. Metan G, Demiraslan H, Kaynar LG, Zararsız G, Alp E, Eser B. Factors influencing the early mortality in haematological malignancy patients with nosocomial Gram negative bacilli bacteraemia: a retrospective analysis of 154 cases. Braz J Infect Dis. 2013; 17(2):143-9.

41. Vigil KJ, Adachi JA, Aboufaycal $H$, Hachem RY, Reitzel RA, Jiang $Y$, et al. Multidrug-resistant Escherichia coli bacteremia in cancer patients. Am J Infect Control. 2009; 37(9):741-5.

42. Liaw CC, Chen JS, Chang HK, Huang JS, Yang TS, Liau CT. Symptoms and signs of port-related infections in oncology patients related to the offending pathogens. Int J Clin Pract. 2008; 62(8):1193-8.

43. Pedrochea CD, Lizasoain M, Medrano FL. Brote nosocomial de gripe en pacientes hematológicos de alto riesgo. Eficacia de las medidas de control y del uso de zanamivir. Enferm Infecc Microbiol Clin.2006; 24(1):10-3.

44. Kumashi P, Girgawy E, Tarrand JJ, Rolston KV, Raad II, Safdar A. Streptococcus pneumoniae bacteremia in patients with cancer: disease characteristics and outcomes in the era of escalating drug resistance (1998-2002). Medicine. 2005; 84(5):303-12.

45. Mühlemann K, Wenger $C$, Zenhäusern R, Täuber MG. Risk factors for invasive aspergillosis in neutropenic patients with hematologic malignancies. Leukemia. 2005; 19(4):545-50.

46. Apisarnthanarak A, Fraser VJ, Dunne WM, Little JR, HoppeBauer J, Jennie L, et al. Stenotrophomonas maltophilia Intestinal Colonization in Hospitalized Oncology Patients with Diarrhea. Clin Infect Dis. 2003; 37(8):1131-35.

47. Alonso-Echanove J, Shah SS, Valenti AJ, Dirrigl SN, Carson LA, Arduino MJ, et al. Nosocomial outbreak of Microbacterium species bacteremia among cancer patients. J Infect Dis. 2001; 184(6):754-60

48. Madani TA. Clinical infections and bloodstream isolates associated with fever in patients undergoing chemotherapy for acute myeloid leukemia. Infection. 2000; 28(6):367-73.

49. Krcmery V Jr, Mrazova M, Kunova A, Grey E, Mardiak J, Jurga $L$, et al. Nosocomial candidaemias due to species other than Candida albicans in cancer patients. Aetiology, risk factors, and outcome of 45 episodes within 10 years in a single cancer institution. Support Care Cancer. 1999; 7(6):428-31.
50. Krcmery V Jr, Oravcova E, Spanik S, Mrazova-Studena M, Trupl J, Kunova A, et al. Nosocomial breakthrough fungaemia during antifungal prophylaxis or empirical antifungal therapy in 41 cancer patients receiving antineoplastic chemotherapy: analysis of aetiology risk factors and outcome. J Antimicrob Chemother. 1998; 41(3):373-80

51. Hornbuckle K, Chak A, Lazarus HM, Cooper GS, Kutteh LA, Gucalp R, et al. Determination and validation of a predictive model for Clostridium difficile diarrhea in hospitalized oncology patients. Ann Oncol. 1998; 9(3):307-11.

52. Ranchere JY, Gordiani B, Bachmann P. Postoperative infections in immunocompromised patients after oncological surgery. Support Care Cancer. 1995; 3(6):409-13.

53. Trupl J, Minarik T, Spanik S, Sufliarsky J, Krcmery V Jr. Nosocomial bacterial and fungal meningitis in cancer patients. Support Care Cancer. 1995; 3(6):425-7.

54. Dauch WA, Krex D, Heymanns J, Zeithammer B, Bauer BL. Peri-operative changes of cellular and humoral components of immunity with brain tumour surgery. Acta Neurochir. 1994; 126(2-4):93-101.

55. Tumbarello M, Trecarichi EM, Caira M, Candoni A, Pastore D, Cattaneo C, Fanci R, et al. Derivation and validation of a scoring system to identify patients with bacteremia and hematological malignancies at higher risk for mortality. PLoS One. 2012; 7(12):516-12.

56. Fanci $R$, Leoni $F$, Longo $G$. Nosocomial infections in acute leukemia: comparison between younger and elderly patients. New Microbiol. 2008; 31(1):89-96.

57. Hachem RY, Kontoyiannis DP, Boktour MR, Afif C, Cooksley C, Bodey GP, et al. Aspergillus terreus: an emerging amphotericin B-resistant opportunistic mold in patients with hematologic malignancies. Cancer. 2004; 101(7):1594-600.

58. WeinstockDM, Conlon M, Iovino C, Tanya Aubrey T, Gudiol C, Riedel E, et al. Colonization, Bloodstream Infection, and Mortality Caused by Vancomycin-Resistant Enterococcus Early after Allogeneic Hematopoietic Stem Cell Transplant. Biol Blood Marrow Transplant. 2007; 13(5)):615-21.

59. Heard SR, Wren B, Barnett MJ, Thomas JM, Tabaqchali S. Clostridium difficile infection in patients with haematological malignant disease. Risk factors, faecal toxins and pathogenic strains. Epidemiol Infect. 1988; 100(1):63-72.

60. Maeda T, Babazono A, Nishi T, Matsuda S, Fushimi K, Fujimori K. Quantification of the effect of chemotherapy and steroids on risk of Pneumocystis jiroveci among hospitalized patients with adult T-cell leukaemia. Br J Haematol. 2015; 168(4):501-6.

61. Mohri Y, Tonouchi H, Miki C, Kobayashi M, Kusunoki M. Incidence and risk factors for hospital-acquired pneumonia after surgery for gastric cancer: results of prospective surveillance. World J Surg. 2008; 32(6):1045-50. 
62. Wang Z, Xin-Jun Cai, Shi L, Fei -Yan Li, Neng-Ming Lin. Risk Factors of Postoperative Nosocomial Pneumonia in Stage a Lung Cancer Patients. Asian Pac J Cancer Prev.2014; 15(7):3071-74

63. Hernández-Navarrete MJ, Arribas-Llorente JL, Solano-Bernad VM, Misiego-Peral A, Rodríguez-García J, Fernández-García JL, et al. Programa de mejora de la infección nosocomial en cirugía por cáncer colorrectal. Medicina Clínica.2005; 125(14):521-524.

64. Jeong BH, Koh WJ, Yoo H, Park HY, Suh GY, Chung MP, et al. Risk factors for acquiring potentially drug-resistant pathogens in immunocompetent patients with pneumonia developed out of hospital. Respiration. 2014; 88(3):190-8.

65. Piper HG; Wales PW; Prevention of catheter-related blood stream infections in children with intestinal failure. Current Opinion in Gastroenterology, 2013 Jan; 29(1): 1-6. (6p)

66. Zamvar, Veena; Lazonby, Gill; Puntis, John W L; Recurrent lifethreatening sepsis in intestinal failure: transplantation or foster care? ArchivesofDisease in Childhood, Jul2013; 98(7): 556-557. $(2 p))$.

67. Andrade AM, Borges KS, Lima HO. Avaliação das coberturas para sítio de inserção do cateter venoso central no tmo: análise de custos. Rev. Min. Enferm.2011, abr./jun; 15(2): 233-241.

68. Menezes VPS, Bittencourt AR, Menezes MFB. Infection related to central venous catheter: indicator of quality of care in oncology. J. res.: fundam. care. online 2013. jul./set. 5(3):373385

69. Nakamura, Itaru; Fukushima, Shinji; Hayakawa, Tsukako; Sekiya, Kentaro; Matsumoto, Tetsuya. The additional costs of catheterrelated blood stream infections in intensive care units.; American JournalofInfectionControl, Oct2015; 43(10): 1046-1049. (4p))

70. Schwam, Zachary G; Sosa, Julie A; Roman, Sanziana; Judson, Benjamin L; Complications and mortality following surgery for oral cavity cancer: analysis of 408 cases. Laryngoscope, Aug2015; 125(8): 1869-1873. (5p)

71. Feitosa RGF, Fernandes AM, Narciso Jr J, Araújo Jr ON, Costa FA, Cavalcante LDW. Incidência de infecção de sítio cirúrgico. Medicina (Ribeirão Preto) 2014; 47(2):157-64

72. Okuno, Emico. Efeitos biológicos das radiações ionizantes: acidente radiológico de Goiânia. Estud. São Paulo 2013; 27(77): 185-200

73. Sneider EB, Davids JS. Effect of chemotherapy, radiation, or immunosuppression on the integrity of the intestinal anastomosis. Seminars in Colon \& Rectal Surgery, Jun2014; 25(2): 105-109. (5p)

74. Hawkey, C.J., Jaime Bosh, Joel e. Richter, Guadalupe Garcia - Tsao, Francis k. L. Chan. Infective diarrhea. textbookof clinicalgastroenterologyandhepatology 2012; 2.

75. Checkley W, Jr ACW, DevanJaganath MJ et al. A review of the global burden, novel diagnostics, therapeutics, and vaccine targets for cryptosporidium. The Lancet Infectious Diseases. 2015; $15(1): f$ 85-94
76. Rodrigues FMMachado. Tabagismo e mecanismos de defesa: resposta imune e transporte mucociliar. Dissertação de Mestrado. São Paulo. 2012: 108

77. Oliveira AC. Healthcare-associated infections in the context of patient safety: past, present and future. Rev Min Enferm. 2013 jan/mar; 17(1): 221-224

78. DerbliSchafranski $M$, Merlini AB, Conrado A, Júnior JRF. Incidência de Efeitos Adversos relacionados à Prednisona em Ensaios Clínicos Randomizados e Controlados com seguimento superior a um ano. Rev. Bras. Med. Interna 2014; 1(1):49-59

79. Paiva $C L$, Zani LB, Duarte ID, Jonis-Silva MDA. Uso Indiscriminado de Antibióticos e Superbactérias KPC: Temas CTS Controverso no Ensino de Biologia. Revista Eletrônica Debates em Educação Científica e Tecnológica.2013 jun; 03(1):32-40.

80. Ortega F Pablo Antonio, Leal M JorymarYoselyn, Chávez Carlos Javier, Mejías C Lidia, Chirinos Q Noraima, Escalona V Carolina del Pilar. Anemia y depleción de las reservas de hierroen adolescentes gestantes de una zona urbana y rural del estado Zulia, Venezuela. Rev. chil. nutr. 2012; 39(3): 11-17.

81. Cantagalli, M R et al. Associação entre desnutrição energéticoprotéica e infecção respiratória aguda em crianças na atenção primária à saúde. Rev. APS, Juiz de Fora2010; jan/mar. 13(1): 26-33

82. McKane,Caitlin K.; MelinaMarmarelis, Mallika L. Mendu, MD, TakuhiroMoromizato, Fiona K. Gibbons, Kenneth B. Christopher. Diabetes mellitus and community-acquired blood stream infections in the criticallyill. Journal of CriticalCare 29 (2014) 70-76.

83. Wukich ,Dane K., Brandon E. Crim, Robert G. Frykberg, Bedda L. Rosario. NeuropathyandPoorlyControlled Diabetes Increasethe Rate of Surgical Site InfectionAfterFootandAnkleSurgery.J Bone Joint Surg Am. 2014; 96:832-9.

84. Vianna HR, Soares CMB, Tavares MS, Teixeira MM, Silva ACS. Inflamação na doença renal crônica: papel de citocinas. J. Bras. Nefrol. 2011; 33(3): 351-364.

85. Rose DP, Vona-Davis L. Biochemical and molecular mechanisms for the association between obesity, chronic inflammation, and breast cancer. Biofactors. 2014 Jan-Feb; 40(1):1-12.

\section{Publish in International Archives of Medicine}

International Archives of Medicine is an open access journal publishing articles encompassing all aspects of medical science and clinical practice. IAM is considered a megajournal with independent sections on all areas of medicine. IAM is a really international journal with authors and board members from all around the world. The journal is widely indexed and classified Q1 in category Medicine. 